\title{
The Influence of Peer Teaching and Cooperative Learning Models towards Students' Self-Confidence and Cooperation in Learning Volleyball
}

\author{
Tite Juliantine*, Agi Rismanugraha, Dian Budiana \\ Program Studi Pendidikan Jasmani Kesehatan dan Rekreasi \\ Fakultas Pendidikan Olahraga dan Kesehatan \\ Univeristas Pendidikan Indonesia \\ *juliantinetite@gmail.com
}

\begin{abstract}
This study aims to find out how the influence of peer teaching model and cooperative learning model of selfconfidence and student teamwork in volleyball game. This research uses quantitative approach with experimental method which will get a primary data. How to obtain the data, the researcher uses an instrumentation through the dissemination of questionnaires distributed to the respondents (students) SMKN 5 Bandung who follow extracurricular volleyball. The instrument used is a self-confident instrument and instrument of teamwork. The questionnaire distributed in the form of a valid questionnaire that had been used by previous researchers. Sample method used in this research is total sampling with amount of 30 people, where 15 peer teaching model group model and 15 people group of cooperative learning model. Data analysis tools used by researchers in the form of Microsoft Excel 2013. Based on the results of research indicate that: a) peer teaching learning model has effects students' self-confidence; b) peer teaching model has effects student teamwork; c) cooperative learning model has effects students' self-confidence; d) cooperative learning model has effect on student teamwork; e) cooperative learning model has more effects on student selfconfidence; and f) cooperative learning model has more effects on student teamwork.
\end{abstract}

Keywords-learning model; peer teaching; cooperative; selfconfidence; teamwork

\section{INTRODUCTION}

Physical education promotes such important aspects as cognition, affection, and psychomotor. Thus, learning models supporting this needs to be developed. To find effective strategies and ideal learning processes, teachers need to analyzed their students' potentials [1]. based on this thought, students need to have freedom to do self-reflection in learning [2]. Some of the mostly considered effective learning models are peer teaching and cooperative learning.

In Indonesia, students' self-confidence and cooperative works are two of the most frequently found issues in learning, including in physical education. In the context of volleyball learning, students often doubt their own potentials as well as others' potentials leading to their lack of optimum performance.
Peer teaching is defined as a learning model promoting students to actively involved in learning with their peers. In the class, they can discuss, interact, and ask questions with their peers so that one is a tutor to another [3]. In this model, teachers are more of a facilitator. Peer teaching has been proven to be an effective learning model in physical education since it is able to improve the academic time, physical activity, and motoric performance of students [4].

In addition, cooperative learning model is a model using instructions among small groups so that students collaborate with each other to solve a problem [5]. There are a variety of students' background within a group to promote diversity [6].

Based on the aforementioned reasons, this study aimed to investigate the influence of peer teaching and cooperating learning models towards students' self-confidence and cooperation at one of the state vocational high schools in Bandung, Indonesia.

\section{RESEARCH METHOD}

This study administered an experimental method aiming to identify a certain treatment to a certain group. The design used in this study was a pretest-postest control group design.

Table 1 shows the research design used in this study.

TABLE I. PRETEST-PostTEST CONTROL GROUP DESIGN

\begin{tabular}{|c|c|c|}
\hline Group & Treatment & Influence of the treatment \\
\hline$X_{1}$ & $\mathrm{O}_{1}$ & $\mathrm{O}_{3}$ \\
\hline$X_{2}$ & $\mathrm{O}_{2}$ & $\mathrm{O}_{4}$ \\
\hline
\end{tabular}

The population in this study were a group of students joining in a volleyball extracurricular activity in a state vocational high school in Bandung, Indonesia. Through a total sampling technique, there were 30 students selected to be the sample of this study. The students were then divided into two groups comprising peer teaching and cooperative learning models as shown in Table 2. 
TABLE II. DIVISION OF RESEARCH SAMPLE

\begin{tabular}{|c|c|}
\hline Peer Teaching & Cooperative Learning \\
\hline 15 students & 15 students \\
\hline
\end{tabular}

The instrument used in this study is a questionnaire discussing the implementation of both learning models and their influence towards self-confidence and learning cooperation. In the meantime, the research procedure is conducted in the following stages.

\section{A. Stage 1}

- Choosing the topic to study

- Formulating purposes of the study

- Determining respondents of the study

- Making a letter of research permit

- Preparing the learning process

- Creating the questionnaire

\section{B. Stage 2}

- Conducting the pretest and distributing the questionnaire

- Implementing the treatment (peer teaching and cooperative learning models)

- Conducting the posttest and distributing the second questionnaire

\section{Stage 3}

- Collecting the data from pretest and posttest

- Analyzing the data

- Drawing conclusions

\section{RESULTS AND DISCUSSION}

The statistical analyses of the implementation of both learning models and their influence towards students' selfconfidence and learning cooperation are presented in Table 3.

TABLE III. RESULtS OF HYPOTHESIS TEST OF PEER TEACHING AND COOPERATIVE LEARNING MODEL TOWARDS STUDENTS' SELF-CONFIDENCE AND LEARNING COOPERATION

\begin{tabular}{|c|c|c|c|}
\hline Variable Y & t-cal & t-table & Conclusion \\
\hline \multicolumn{4}{|c|}{ Peer Teaching } \\
\hline Self-confidence & $-4,00$ & 2,048 & Influential \\
\hline Learning cooperation & $-3,82$ & 2,048 & Influential \\
\hline \multicolumn{4}{|c|}{ Cooperative Learning } \\
\hline Self-confidence & $-4,71$ & 2,048 & Influential \\
\hline Learning cooperation & $-5,09$ & 2,048 & Influential \\
\hline
\end{tabular}

The results in Table 3 indicated that peer teaching has a positive impact towards students' self-confidence. This is in line with a study stating that peer teaching is effective in improving students' self-confidence [7]. Another conclusion from the table is that peer teaching is influential towards the improvement of students' cooperation in learning. A study by Umar revealed that students cooperate with each other well when given more chances to do so [8]. Moreover, the statistical computation proved that the cooperative learning model implemented in this study was effective to enhance students' self-confidence and learning cooperation. This is due to the fact that the small group members within the learning are heterogeneous triggering the students to be more active and collaborative with one another [9]. Table 4 shows the results of hypothesis test between both learning models.

TABLE IV. RESUlts OF HyPOTHESIS TEST OF PEER TEACHING AND COOPERATIVE LEARNING MODELS

\begin{tabular}{|l|c|c|c|}
\hline \multicolumn{1}{|c|}{ Learning Model } & $\overline{\overline{\mathbf{x}}}$ pretest & $\overline{\mathbf{x}}_{\text {posttest }}$ & Difference \\
\hline \multicolumn{4}{|c|}{ Self-Confidence } \\
\hline Peer Teaching & 230,47 & 260,13 & 29,67 \\
\hline Cooperative Learning & 185,67 & 243,67 & 58 \\
\hline \multicolumn{4}{|c|}{ Cooperation } \\
\hline Peer Teaching & 149,13 & 165,40 & 16,27 \\
\hline Cooperative Learning & 111,27 & 157,33 & 46,06 \\
\hline
\end{tabular}

The results presented by Table 4 indicated that cooperative learning is more effective in promoting students' selfconfidence in comparison with peer teaching. In the meantime, it has also been proven by the statistical computation in Table 4 that cooperative learning is also more effective in promoting students' cooperation in learning compared to peer teaching. This is in line with the results of a study by Rubiyanto pointing out that cooperative learning gives students more opportunities to be collaborating with their friends, either among their group members or with ones from other groups [10].

\section{CONCLUSION}

Based on the data analysis, it has been found that both peer teaching and cooperative learning models are influential towards students' self-confidence and learning cooperating in the context of physical education, particularly in learning volleyball. However, cooperative learning seems to be more effective in promoting students' self-confidence and learning cooperation in comparison with peer teaching learning model. It is recommended that further researchers focus more that contributing factors of students' self-confidence and learning cooperation in learning volleyball and other types of sport.

\section{REFERENCES}

[1] USDE, Physical Education Standards. Amerika: NBPTS, 2014

[2] M. Bronikowski, Physical Education Teaching and Learning. Polandia: Eugeniusza Piaseckiego, Akademia Wychowania Fizycznego, 2010.

[3] F. d'Arripe-Longueville, "Peer Tutoring in a Physical Education Settings: Influence of Tutor Skill Level on Novice Learness Motivation and Performance," Journal of Teaching in Physical Education, pp. 105 123, 2016.

[4] A.M. Nurmi and M. Kokkonen, "Peer as Teachers in Physucal Education Hip Hop Classes in Finnish High School," Journal of Education and TRaining Studies, Vol. 3, No. 3, 2015.

[5] G. Jacobs, Cooperative Learning: Theory, Principles, and Tehniques, 2016, pp.1-10. 
[6] J. Siswanto and S. Rechana, "Pengaruh Model Pembelajaran Kooperatif Tipe NHT (Numbered Heads Together) Menggunakan Peta Konsep dan Peta Pikiran Terhadap Penalaran Formal Siswa," JP2F, Vol. 2, No. 2, pp. 178-188, 2011

[7] W.Y. Fadly, Penerapan Strategi Peer Tutoring untuk Menngkatkan Rasa Percaya Diri Siswa dalam Pelajaran Matematika (PTK Pada Siswa Kelas X MIPA 1 SMA Negeri 1 Kayen Semester Ganjil Tahun AJaran 2017/2018). Surakarta: FKIP Universitas Muhammadiyah Surakarta, 2018
[8] T. Umar, "Pengaruh Outbond Training Terhadap Peningkatan Rasa Percaya Diri Kepemimpinan dan Kerjasama Tim," Jurnal Ilmiah SPIRIT, Vol. 11, No. 3, pp. 59-69, 2011.

[9] Nurdyansyah and E.F. Fahyuni, Inovasi Model Pembelajaran Sesuai Kurikulum 2013. Sidoarjo: Nizamia Learning Center, 2016.

[10] R. Rubiyanto, "Model Pembelajaran Peer-Teaching Untuk Meningkatkan Kemampuan Verbal Mahasiswa PGSD FKIP UMS,' Profesi Pendidikan Dasar, Vol. 2, No. 1, pp. 132-140, 2014. 